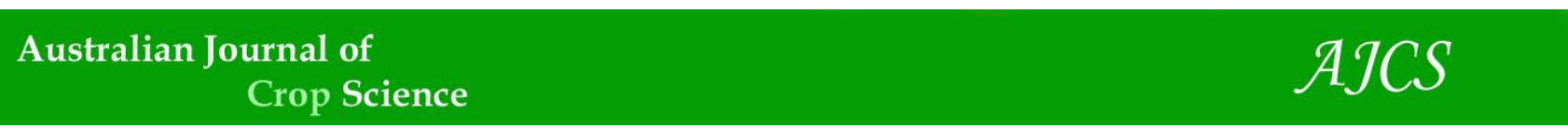

AJCS 15(12):1478-1484 (2021)

ISSN:1835-2707

doi: 10.21475/ajcs.21.15.12.p3425

\title{
Effects of mulching on the weed community and grain yield of upland rice cultivars
}

\section{Givago Lopes Alves ${ }^{1}$, Raimundo Nonato Viana Santos ${ }^{1}$ Antônia Alice Costa Rodrigues ${ }^{1}$ Maria José Pinheiro Correa ${ }^{2}$ Mário Luiz Ribeiro Mesquita ${ }^{3}{ }^{*}$ Maria Rosângela Malheiros Silva ${ }^{1}$}

\author{
${ }^{1}$ Universidade Estadual do Maranhão, Programa de Pós-Graduação em Agroecologia, São Luís, Maranhão, Brasil \\ ${ }^{2}$ Universidade Estadual do Maranhão, Departamento de Química e Biologia, São Luís, Maranhão, Brasil \\ ${ }^{3}$ Universidade Estadual do Maranhão, Programa de Pós-Graduação em Agricultura e Ambiente UEMA, Brasil
}

\author{
*Corresponding author: mario-mesquita51@hotmail.com
}

\section{Abstract}

This study evaluated the effects of mulching on upland rice cultivars Comecru and Cambará and the weed community under four amounts of babassou (Attalea speciosa Mart. ex Spreng.) straw mulching namely: 0, 15, 20, $25 \mathrm{t} \mathrm{ha}^{-1}$ with a view to control weeds. The experiment was laid out in a randomized complete block design in a $2 \times 4$ factorial scheme with four replications. The rice plant height, percentage of fertile panicles, number of spikelets per panicle, weight of 100 grains and grain yield were assessed. We also assessed the weed community by computing the following phytosociological parameters: density, frequency and the importance value index (IVI) of each species. Babassou straw mulching reduced weed density and dry mass between rows of upland rice cultivars and increased the rice yield. The weed species with the highest Importance Value Index (IVI) in the treatments with no mulching were Cyperus iria, Fimbristylis dichotoma and Digitaria ciliaris. Rice grain yield was increased with the increase in the amount of straw. Comecru cv. had the highest suppressive effect on weeds with significantly higher grain yield $\left(1,214.85 \mathrm{~kg}^{-1}\right)$ than Cambará cv. (878.72 kg ha $\left.{ }^{-1}\right)$. We conclude that the higher amounts (20 and $\left.25 \mathrm{t} \mathrm{ha}^{-1}\right)$ of babassou straw mulching suppressed weeds, providing less competition with the rice cultivars, which resulted in an increase in the number of rice panicles, weight of 100 grains, spikelet fertility and grain yield in both rice cultivars.

Keywords: Oryza sativa L., competition, allelopathy.

Abbreviations: DAE_days after emergence; $\mathrm{R}$ De_relative density; $\mathrm{R}$ Fr_relative frequency $\mathrm{R}$ Do_relative dominance; IVI_importance value index.

\section{Introduction}

Rice (Oryza sativa L.) is one of the most consumed cereals in Brazil and in the world, covering the five continents in tropical and subtropical regions. In Brazil, production was approximately 10.26 million tons in 2019 with the northeast region accounting for $3.1 \%$ (318 thousand tons) and the state of Maranhão having the largest production in the region, 167.5 thousand tons (Companhia Nacional de Abastecimento - CONAB, 2019).

Weeds are a major biological constraint in rice cultivation. Weeds compete with rice for nutrients, water, space, light and $\mathrm{CO} 2$, which leads to decreasing grain yield and deterioration in product quality (Khan et al., 2013). In the absence of weed control, rice grain yield reduction may reach up to $85 \%$ (Silva et al., 2015).

Hussain et al. (2015) reported that the intensity of yield losses caused by weeds depends on the species, density, emergence time and duration of interference. Ali et al. (2015) cited that yield losses are more severe when weeds emerge simultaneously with the crop. Thus, the management of weeds in rice crops is essential to reduce grain yield losses.

Among the various weed management techniques in upland rice cultivation, Jabran et al. (2015) reported the use of weed suppressor cultivars combined with other methods. The authors highlighted the rapid canopy development and allelopathy as important characteristics of rice cultivars for weed suppression. Sardana et al. (2016) added high biomass production and leaf area index of rice cultivars.

The rapid growth and development of the canopy of rice cultivars that occupy the growth space delay the emergence and development of weeds decreasing competition (Dass et al., 2017). In addition, they avoid the replenishment of seeds in the weed seed bank of soils (Sardana et al., 2016).

The combination of competitive rice cultivars with mulching can improve weed management in rice cultivation. Jabran et al. (2015) reported that mulching could influence the germination and emergence of many weed species by changing the chemical and physical environments surrounding the weed seeds in the soil.

According to Sardana et al. (2016), we can improve the competitive capacity of crops by different cropping practices that facilitate soil surface coverage through rapid growth and expansion of the crop canopy. Among these cropping practices, authors highlighted that mulching can promote greater soil humidity for the development of the crop, among other benefits.

There are several types of mulching made with plant residues that have been efficient in weed suppression such as sugarcane bagasse (Juang et al., 2021) and coffee husks (Liu et al., (2020). In the state of Maranhão, a vegetal cover 
of the babassou palm leaves (Attalea speciosa Mart. Ex Spreng.) is widely used by family farmers to control weeds (Mesquita et al., 2019). This palm is very abundant in the region, the leaves are placed between rows of annual crops, but there is no definition of the adequate amount to reduce weed infestation.

The knowledge of the amount of residues to suppress weeds helps to reduce labor costs for obtaining biomass. However, quantity is as important as quality of residues for weed suppression (Nichols et al., 2015).

Considering the scarcity of information about the amount of babassou straw with the greatest potential for weed suppression in the region, this study aimed to evaluate the effect of different amounts of crushed babassou straw mulching on the weed community and grain yield of two rice cultivars.

\section{Results and discussion}

\section{Effect of babassou straw mulch on weeds}

Overall, we identified 22 weed species from 14 families. Seven species were from the monocotyledonous group and 15 from eudicotyledonous. The babassou straw mulch weed suppression was higher in the eudicotyledonous (10 species) than in the monocotyledonous (four species) (Table 1).

The Cyperaceae family had the highest species richness with four species. Silva et al. (2017) reported similar results and Costa et al. (2018) in a survey of weeds in upland rice crop also found the Cyperaceae family as the most relevant in the State of Maranhão, northeast Brazil.

The Cyperaceae family species are very competitive with the rice crop, as they have morphological characteristics similar to the crop. Dass et al. (2017) highlighted that the competition between rice and weeds is more severe when the root system, morphology and growth habit of most species in the weed community are similar to the rice plants. The weed species richness was higher in both rice cultivars in the absence of mulch. This can be attributed to the direct incidence of light on the soil, stimulating weed seed germination from the seed bank in the soil. Wayayok et al. (2014) also found greater weed diversity in upland rice grown without mulching.

In the absence of babassou straw, we noted the occurrence of 18 species from 14 families in the cultivar Comecru and 14 species from 10 families in the cultivar Cambará. In contrast, in the presence of babassou straw mulching, we recorded an average of 14 species in the cultivar Comecru and 12 in the cultivar Cambará (Table 1).

\section{Effect of babassou straw mulch on rice cultivars}

Rice cultivars differed significantly from each other with respect to weed competition in the absence of babassou straw. Comecru cv. had lower weed density ( 246 plants $\mathrm{m}^{-2}$ ) than Cambará ( 810 plants $\mathrm{m}^{-2}$ ). Larger sized Comecru cv. with broad and decumbent leaves probably shaded the soil more quickly than smaller Cambará cv. with narrow and erect leaves, which resulted in less weed germination and emergence.

Dass et al. (2017) highlighted that cultivars with rapid growth and canopy development soon occupy space and establish quickly. Therefore, they delay weed emergence and decrease competition.

The babassou straw mulch suppressed the weed density from 60 to $69 \%$ in cultivar Comecru and 80 to $87 \%$ in Cambará (Figure 2).
Based on the results obtained from this study, it could be inferred that babassou straw mulching inhibited weed emergence by reducing sunlight and a physical barrier to weed germination and emergence (Jabran et al., 2015).

Regarding weed dry mass accumulation, both rice cultivars also differed significantly in $0 \mathrm{t} \mathrm{ha}^{-1}$ of babassou straw mulching, with the highest accumulations in Cambará (332 g $\mathrm{m}^{-2}$ ) and the lowest in Comecru $\left(103 \mathrm{~g} \mathrm{~m}^{-2}\right)$. The amounts of straw did not affect the dry mass of weeds in the Comecru cultivar, but in Cambará the greatest accumulations were occurred at $0 \mathrm{t}$ ha-1 (Figure 3 ).

The higher weed density in the Cambará cv. resulted in the high accumulations of weed dry mass. This is probably related to the morphological characteristics of the rice cultivar. Sardana et al. (2016) reported that the morphological, physiological and metabolic characteristics of crops influence their ability to use resources (water, light, nutrients and space) in the presence of weeds.

Although in cultivar Comecru cv. the effect of straw was similar when compared with the absence of straw, it was observed that in the treatment with $25 \mathrm{t} \mathrm{ha}^{-1}$ there was a $54 \%$ reduction in the weed dry mass accumulation. The morphological characteristics of the cultivar associated with the physical barrier of babassou straw may have contributed to the lower weed dry mass accumulation.

According to Dass et al. (2017) plant height, rapid canopy development, profuse tillering, horizontal leaf, greater leaf area index in addition to high dry matter accumulation before the reproduction phase are important characteristics of the rice plant to compete with weeds.

Ranaivoson et al. (2018) found that weed biomass was decreased with increasing amounts of plant residues on the soil, requiring more than $10 \mathrm{t} \mathrm{ha}^{-1}$ to reduce significantly weed emergence and biomass, compared to soil treatment without surface residues.

The weed species with higher IVI in $0 \mathrm{t}$ ha-1 of babassou straw in both rice cultivars were $F$. dichotoma, $D$. ciliaris, $L$. leptocarpa, E. colona and C. iria. In the presence of babassou straw, the IVI of $F$. dichotoma D. ciliaris, L. leptocarpa and $E$. colona were reduced, but the IVI of $C$. iria and $A$. tenella increased with babassou straw additions (Table 2).

In a study of weed interference in rice crop, Silva et al. (2015) also mentioned these species, except E. colona. They caused yield losses of 83.4 and 71\%. Peerzada et al. (2016) reported E. colona as persistent weed in crops due to its high seed production, low dormancy and germination over wide temperature ranges. Moreover, it has strong allelopathic effect and is resistant to various herbicides.

The reduction of the IVI of $F$. dichotoma, D. ciliaris, $L$. leptocarpa and $E$. colona with the additions of straw in the cultivars indicate that the effect of mulching was effective in suppressing these weed species. However, as the IVI of $C$. iria and $A$. tenella increased, it suggests that the effect can also be stimulatory and that it varies according to the weed. Awan et al. (2015) cited C. iria as a species that causes high yield losses and increases its height to compete with rice in the presence of nitrogen. Chopra et al. (2017) pointed out its strong allelopathic effect on rice, inhibiting seedling germination and growth. The cultivars differed from each other for plant height, which the highest values were reached by the Comecru cv. in the treatment with $20 \mathrm{t} \mathrm{ha}^{-1}$ $(104.45 \mathrm{~cm})$ and $25 \mathrm{t} \mathrm{ha}^{-1}(108.20 \mathrm{~cm})$. There were no differences between the straw treatments in Cambará cv., the height ranged from 95.23 to $96.02 \mathrm{~cm}$. The smallest 
Table 1. Class, family and weed species documented at harvest of Comecru and Cambará rice cultivars under different amounts of babassou straw mulch in the municipality of Arari, state of Maranhão, northeast Brazil 2016.

\begin{tabular}{|c|c|c|c|c|c|c|c|c|c|}
\hline \multirow[t]{2}{*}{ Family } & \multirow[t]{2}{*}{ Species } & \multicolumn{4}{|c|}{$\begin{array}{l}\text { Babassou straw } \\
\text { mulch }\left(\mathrm{t} \mathrm{ha}^{-1}\right) \text { in } \\
\text { ComeCru rice cv. }\end{array}$} & \multicolumn{4}{|c|}{$\begin{array}{l}\text { Babassou straw } \\
\text { mulch }\left(t \mathrm{ha}^{-1}\right) \text { in } \\
\text { Cambará rice cv. }\end{array}$} \\
\hline & & 0 & 15 & 20 & 25 & 0 & 15 & 20 & 25 \\
\hline \multicolumn{10}{|l|}{ Monocotyledons } \\
\hline \multirow[t]{2}{*}{ Commelinaceae } & Murdannia nudiflora L. & & & & & & & & \\
\hline & & $\mathrm{x}$ & --- & $\mathrm{x}$ & $\mathrm{x}$ & $\mathrm{x}$ & --- & $\mathrm{x}$ & $\mathrm{x}$ \\
\hline \multirow[t]{6}{*}{ Cyperaceae } & Cyperus iria L. & & & & & & & & \\
\hline & & $\mathrm{x}$ & $\mathrm{x}$ & $\mathrm{x}$ & $\mathrm{x}$ & $\mathrm{x}$ & $\mathrm{x}$ & $\mathrm{x}$ & $\mathrm{x}$ \\
\hline & Cyperus odoratus L. & & & & & & & & \\
\hline & & $\mathrm{x}$ & --- & --- & --- & $\mathrm{x}$ & --- & --- & --- \\
\hline & Eleocharis sellowiana Kunth & $\mathrm{x}$ & $\mathrm{x}$ & --- & $\mathrm{x}$ & $\mathrm{x}$ & $\mathrm{x}$ & --- & $\mathrm{x}$ \\
\hline & Fimbristylis dichotoma (L) Vahl & $\mathrm{x}$ & $\mathrm{x}$ & $\mathrm{x}$ & $\mathrm{x}$ & $\mathrm{x}$ & $\mathrm{x}$ & $\mathrm{x}$ & $x$ \\
\hline \multicolumn{10}{|l|}{ Poaceae } \\
\hline & Digitaria ciliaris (Retz.) Koeler & $x$ & $x$ & $x$ & $x$ & $x$ & $x$ & $x$ & $x$ \\
\hline & Echinochloa colona (L) Link & $\mathrm{x}$ & $\mathrm{x}$ & $\mathrm{x}$ & --- & $\mathrm{x}$ & $\mathrm{x}$ & $\mathrm{x}$ & $\mathrm{x}$ \\
\hline \multicolumn{10}{|l|}{ Eudicotyledons } \\
\hline \multicolumn{10}{|l|}{ Amaranthaceae } \\
\hline & Alternanthera tenella Colla & $\mathrm{x}$ & $x$ & $x$ & $x$ & $\mathrm{x}$ & $x$ & $x$ & $x$ \\
\hline & Alternanthera brasiliana (L.)Kuntze & $x$ & $x$ & $x$ & --- & --- & --- & --- & --- \\
\hline \multirow[t]{2}{*}{ Convolvulaceae } & Aniseia cernura Moric.. & & & & & & & & \\
\hline & & $\mathrm{x}$ & $\mathrm{x}$ & $\mathrm{x}$ & --- & --- & --- & --- & --- \\
\hline \multirow[t]{4}{*}{ Fabaceae } & & $x$ & --- & --- & --- & --- & --- & --- & --- \\
\hline & Senna sp. & & & & & & & & \\
\hline & Aeschynomene sensitiva Sw & $x$ & --- & --- & --- & --- & --- & --- & --- \\
\hline & Senna uniflora $\mathrm{L}$ & --- & --- & --- & $x$ & --- & --- & --- & --- \\
\hline \multicolumn{10}{|l|}{ Lamiaceae } \\
\hline & Marsypianthes chamaedrys L. & $\mathrm{x}$ & $\mathrm{x}$ & $x$ & $\mathrm{x}$ & $x$ & $x$ & $x$ & --- \\
\hline \multicolumn{10}{|l|}{ Euphorbiaceae } \\
\hline & Croton grandulosus L. & --- & --- & --- & $\mathrm{x}$ & --- & --- & --- & --- \\
\hline \multicolumn{10}{|l|}{ Linderniaceae } \\
\hline & Lindernia crustacea $\mathrm{L}$. & $\mathrm{x}$ & $\mathrm{x}$ & $\mathrm{x}$ & $\mathrm{x}$ & $\mathrm{x}$ & $\mathrm{x}$ & $\mathrm{x}$ & $\mathrm{x}$ \\
\hline \multicolumn{10}{|l|}{ Malvaceae } \\
\hline & Sida acuta Burn. f. & --- & --- & $\mathrm{x}$ & $x$ & --- & --- & --- & --- \\
\hline \multicolumn{10}{|l|}{ Molluginaceae } \\
\hline & Mollugo verticillata $\mathrm{L}$. & $\mathrm{x}$ & $\mathrm{x}$ & $\mathrm{x}$ & --- & $x$ & $x$ & --- & --- \\
\hline \multicolumn{10}{|l|}{ Onagraceae } \\
\hline & Ludwigia leptocarpa H. (Nutt.) Hara & $\mathrm{x}$ & $\mathrm{x}$ & $\mathrm{x}$ & $\mathrm{x}$ & $\mathrm{x}$ & $\mathrm{x}$ & $\mathrm{x}$ & $\mathrm{x}$ \\
\hline \multicolumn{10}{|l|}{ Phyllanthaceae } \\
\hline & Phyllanthus tenellus L. & $x$ & $x$ & $x$ & $x$ & $x$ & $x$ & $x$ & $x$ \\
\hline & Phyllanthus niruri L. & --- & --- & --- & --- & --- & --- & $x$ & $x$ \\
\hline \multicolumn{9}{|l|}{ Solanaceae } & --- \\
\hline
\end{tabular}




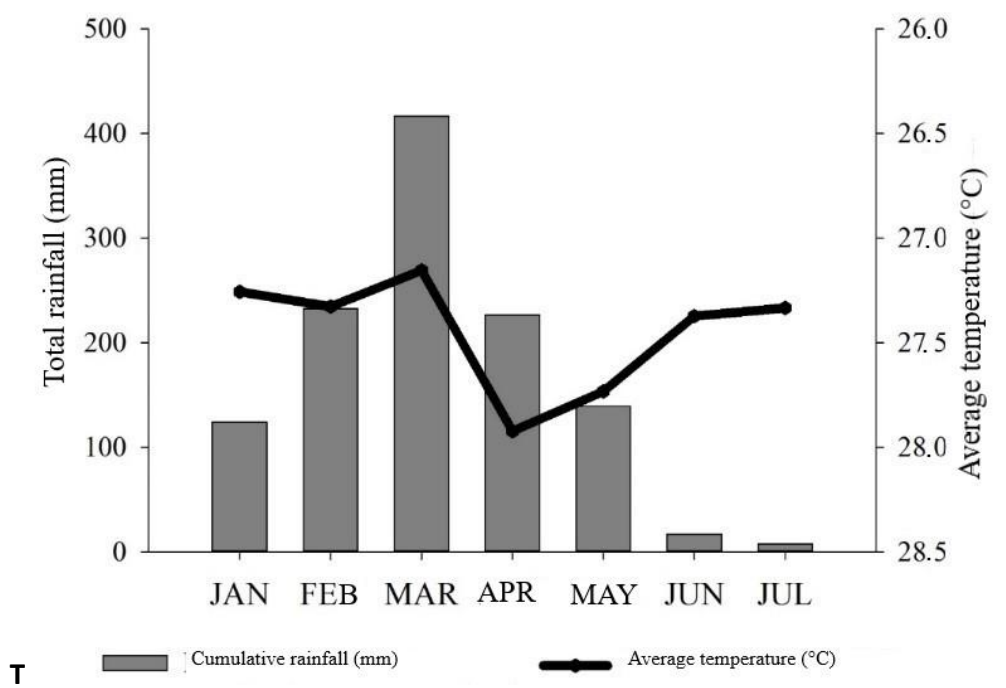

Fig 1. Rainfall and average temperature during the rice crop cycle in the Municipality of Arari state of Maranhão, northeastern Brazil, 2016. Source: NUGEO.

Table 2. Importance value index - IVI (\%) of the main weeds in the rice cultivars Comecru and Cambará with different amounts of babassou straw mulch, in the municipality of Arari, state of Maranhão, northeastern Brazil, 2016.

\begin{tabular}{|c|c|c|c|c|c|}
\hline \multirow[t]{2}{*}{ Cultivar } & \multirow[t]{2}{*}{ Weed species } & \multicolumn{4}{|c|}{ Amount of straw } \\
\hline & & 0 t ha $^{-1}$ & $15 \mathrm{t} \mathrm{ha}^{-1}$ & $20 \mathrm{tha}^{-1}$ & $25 \mathrm{t} \mathrm{ha}^{-1}$ \\
\hline \multirow[t]{6}{*}{ Comecru } & F. dichotoma & 84.99 & 59.41 & 31.93 & 25.64 \\
\hline & D. ciliaris & 60.5 & 24.17 & 28.04 & 28.76 \\
\hline & L. leptocarpa & 40.65 & 20.39 & 15.86 & 22.83 \\
\hline & E. colona & 26.58 & 22.81 & 10.22 & 9.39 \\
\hline & C. iria & 6.44 & 32.78 & 56.33 & 47.07 \\
\hline & A. tenella & 6.71 & 41.7 & 45.23 & 44.26 \\
\hline \multirow[t]{5}{*}{ Cambará } & D. ciliaris & 71.07 & 21.89 & 29.51 & 28.52 \\
\hline & C. iria & 53.43 & 75.39 & 71.49 & 75.80 \\
\hline & F. dichotoma & 52.12 & 30.47 & 25.64 & 26.63 \\
\hline & L. leptocarpa & 33.55 & 21.81 & 23.59 & 15.41 \\
\hline & E. colona & 33.10 & 21.30 & 22.54 & 18.89 \\
\hline
\end{tabular}

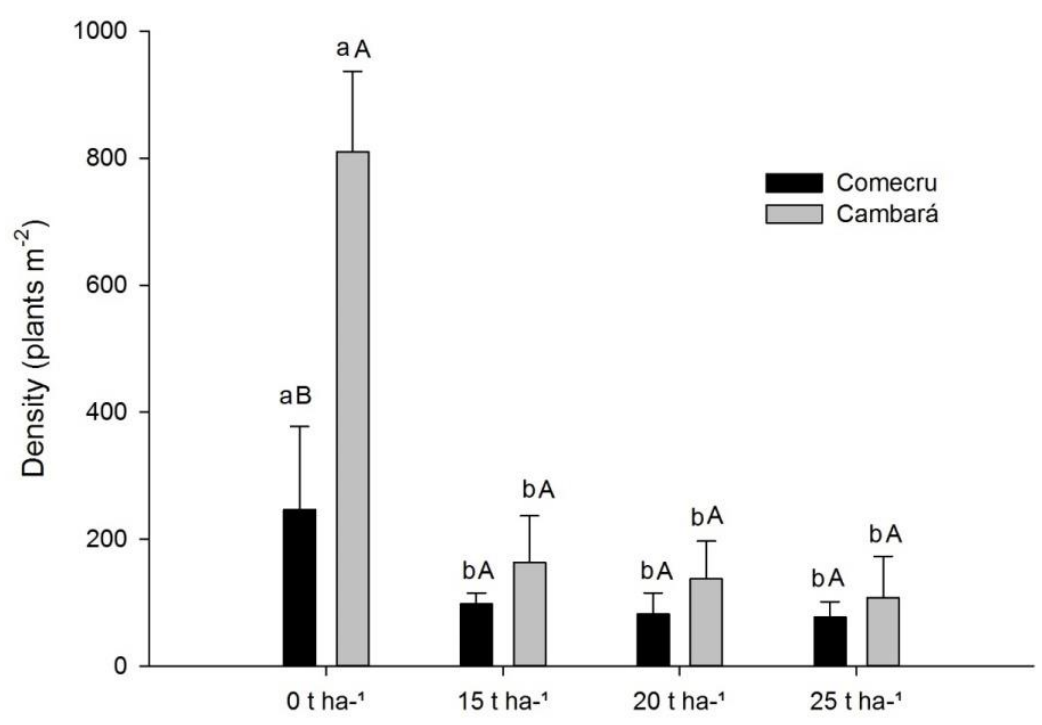

Fig 2. Weed density in different amounts of babassou straw in two rice cultivars in the Municipality of Arri, state of Maranhão, northeast Brasil, 2016. Capital letters compare varieties with each other within the amount of straw and lowercase letters compare the amounts of straw with each other in each variety at $5 \%$ probability by Tukey's test 
Table 3. Number of panicles $\mathrm{m}^{-2}$ (PAN), spikelet fertility (FERT) and grain yield (PROD) of the Comecru and Cambará rice cultivars grown with different amounts of babassou straw mulching in the Municipality of Arari, state of Maranhão, northeast Brazil, 2016.

\begin{tabular}{|c|c|c|c|c|c|c|}
\hline \multirow{2}{*}{$\begin{array}{l}\text { Amount of } \\
\text { straw }\end{array}$} & \multicolumn{2}{|c|}{ PAN } & \multicolumn{2}{|c|}{ FERT. (\%) } & \multicolumn{2}{|c|}{ PROD. $\left(k g h a^{-1}\right)$} \\
\hline & Comecru & Cambará & Comecru & Cambará & Comecru & Cambará \\
\hline $0 t h a^{-1}$ & $36.82 d A$ & $43.92 b A$ & $51.25 \mathrm{Ca}$ & $44.00 \mathrm{bA}$ & $72.27 d A$ & $43.73 d A$ \\
\hline $15 t h a^{-1}$ & $88.36 \mathrm{cA}$ & $97.45 a A$ & $62.33 b A$ & $59.75 a A$ & $442.63 c A$ & $227.83 C B$ \\
\hline $20 t h a^{-1}$ & $88.73 b A$ & $93.80 a A$ & $70.25 \mathrm{Aa}$ & $60.75 a B$ & $724.88 b A$ & $437.15 b B$ \\
\hline $25 t h a^{-1}$ & $115.80 a A$ & $93.13 a B$ & $72.75 \mathrm{Aa}$ & $56.25 a B$ & $1214.85 a A$ & $828.72 a B$ \\
\hline
\end{tabular}

* Means followed by the same lowercase letter in the columns and uppercase in the rows do not differ by the Scott-Knott test ( $p<$ $0.05)$.

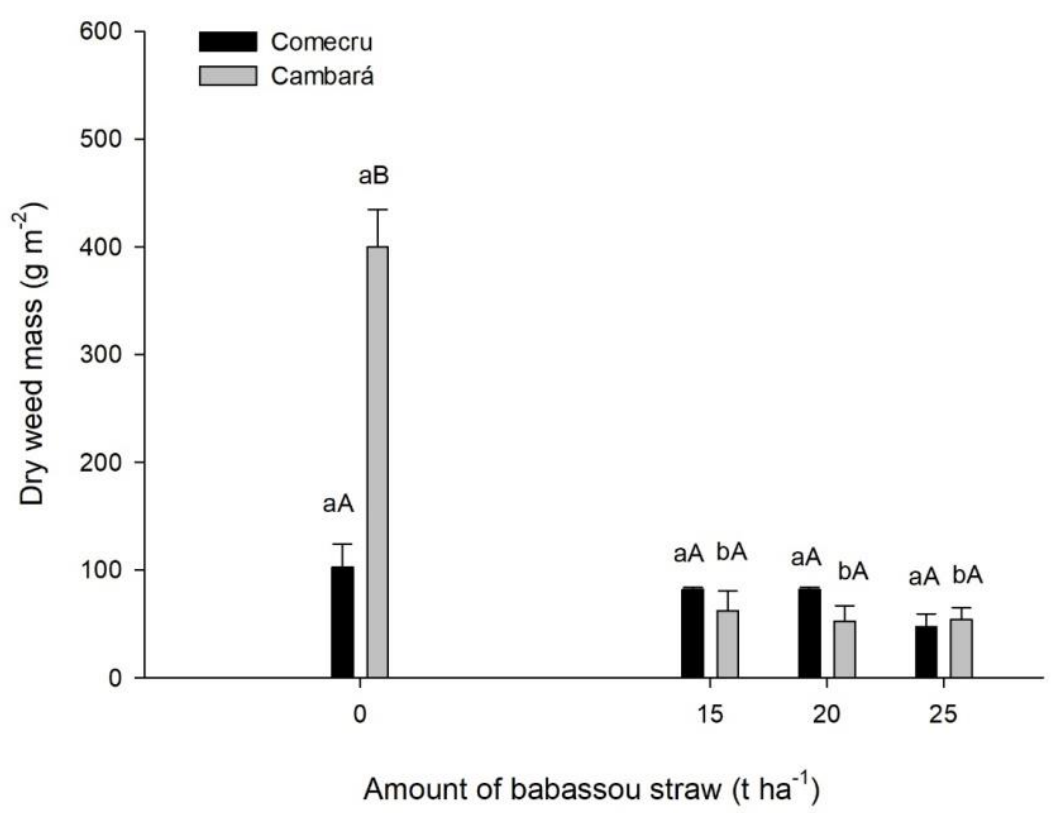

Fig 3. Weed dry mass in different amounts of babassou straw mulching in two rice cultivars in the municipality of Arari, state of Maranhão, northeast Brazil, 2016. Capital letters compare varieties with each other within the amount of straw and lowercase letters compare the amounts of straw with each other in each variety.

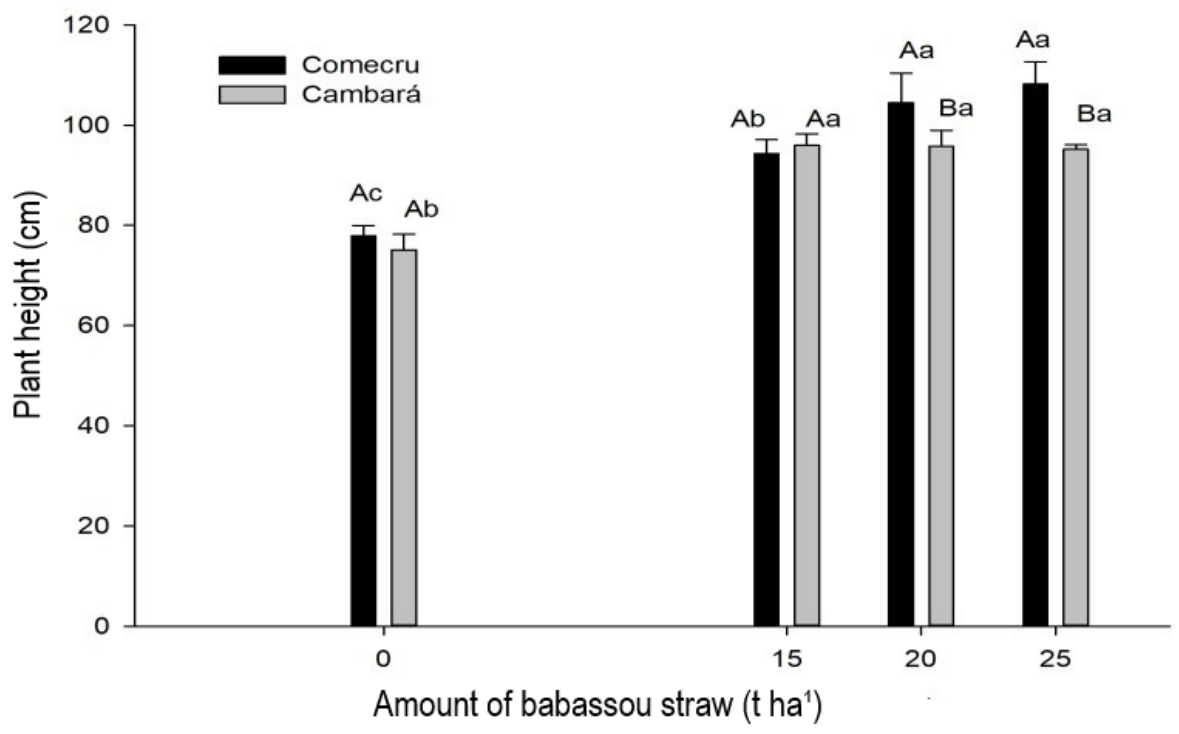

Fig 4. Plant height of Comecru and Cambara rice cultivars grown with different amounts of babassou straw mulching in the Municipality of . Arari, state of Maranhão, northeast Brazil, 2016. Means followed by the same lowercase letter in the columns and uppercase in the rows do not differ by the Scott-Knott test $(p<0.05)$. 
plant heights were observed in $0 \mathrm{t} \mathrm{ha}^{-1}$ with $77.95 \mathrm{~cm}$ for Comecru and $75.15 \mathrm{~cm}$ for Cambará (Figure 4).

Based on the results of this study, it could be inferred that the physical barrier of the soil coverage contributed to the growth of cultivars by suppressing weeds and that the morphological characteristics of the cultivar Comecru also contributed to the reduction of weed density.

The reductions of $28 \%$ in the plant height of the cultivar Comecru of and of $22 \%$ in Cambará due to the absence of straw show the relevance of weed management to reduce interference on the rice crop. Prasad (2011) reported that traditional rice cultivars are generally taller and have a greater suppressive effect on weeds. Sana et al. (2017) also reported that the height of the rice plant was significantly lower when competing with weeds.

The number of rice panicles $\mathrm{m}^{-2}$ and spikelet fertility was significantly affected by cultivars and amounts of straw. Cultivar Comecru produced more panicles $\mathrm{m}^{-2}$ in $25 \mathrm{t} \mathrm{ha}^{-1}$ and fertile spikelets ( 20 and $25 \mathrm{t} \mathrm{ha}^{-1}$ of straw) compared to Cambará. The absence of straw reduced these two parameters in cultivars (Table 4).

There were no significant differences among the amounts of straw between the rice cultivars for the weight of 100 grains. Except at $25 \mathrm{t} \mathrm{ha}^{-1}$ with higher values presented by cultivar Comecru.

Grain fertility was also differed between rice cultivars with higher values in cultivar Comecru at 20 and $25 \mathrm{t} \mathrm{ha}^{-1}$. In both cultivars, the absence of straw cover decreased grain fertility (Table 4).

Rice grain yield differed significantly between cultivars in treatments with straw, where the highest values were reached by Comecru. The amounts of straw increased the yield by $94.05 \%$ for Comecru and $95 \%$ for Cambará compared to the absence of straw (Table 4).

The higher yield of cv. Comecru is possibly related to the greater synergy of its morphological characteristics with the straw cover for weed suppression.

The high amounts of straw suppressed weeds, providing less competition with the rice crop, resulted in an increase in both cultivar yields. Ranaivoson et al. (2018) also verified higher rice crop yields with high amounts of Stylosanthes spp. residue soil cover (18.3 $\left.\mathrm{t} \mathrm{ha}^{-1}\right)$ and in corn with Dolichos spp. $\left(27.6 \mathrm{t} \mathrm{ha}^{-1}\right)$.

There was a high negative impact of weeds on rice cultivars when there was no application of babassou straw mulching, indicating low competitive ability of the rice crop. Ranaivoson et al. (2018) showed a higher level of weed infestation and an average reduction of $59 \%$ in rice yields in soils without mulching.

\section{Materials and methods}

\section{Study site: location and characteristics}

The research was conducted from January to April 2016 in a rural area located in following coordinates $03.27^{\prime} 13^{\prime \prime} S$ and 44ำ4' $48^{\prime \prime} \mathrm{W}$, in the municipality of Arari, state of Maranhão, northeastern Brazil.

The climate in the region, according to Köppen classification, is tropical (AW') with a rainy season, from January to June and a dry season, from July to December. The average rainfall is $1,656 \mathrm{~mm}$. Climatic data for average temperature and rainfall during the crop cycle are shown in Figure 1.

Soil samples were taken at a depth of $0-20 \mathrm{~cm}$ in the experimental area to determine the physicochemical characteristics, with the following results: fine sand $=1 \%$; clay $=14 \%$, silt $=85 \%$ and coarse sand $=0 \%$; organic matter $=13 \mathrm{~g} \mathrm{dm}^{-3} ; \mathrm{pH}(\mathrm{CaCl} 2)=4.5 ; \mathrm{P}=53 \mathrm{mg} \mathrm{dm}^{-3} ; \mathrm{K}=5.2 \mathrm{mmol}$ $\mathrm{dm}^{-3} ; \mathrm{Ca}=27 \mathrm{mmol} \mathrm{dm}{ }^{-3} ; \mathrm{Mg}=0 \mathrm{mmol} \mathrm{dm}{ }^{-3} ; \mathrm{H}+\mathrm{Al}=31$ mmolc $\mathrm{dm}^{-3}$. The soil in the area is of the silty loam texture type (Santos et al. 2013).

Soil preparation was carried out with manual mowing. We applied NPK fertilization at planting with $220 \mathrm{~kg} \mathrm{ha}^{-1}$ of the 530-15 formulation and top dressing with $30 \mathrm{~kg} \mathrm{ha}^{-1} \mathrm{~N}$ with 91 $\mathrm{kg} \mathrm{ha}^{-1}$ of urea applied at 40 days after crop emergence (DAE).

\section{Plant materials}

Sowing of the rice cultivars Cambará and Comecru was manual with 100 seeds $\mathrm{m}^{-1}$. Cultivar Cambará presents modern plant architecture, medium size, 86 days cycle and high grain yield while Comecru is characterized by its tallest size $(106 \mathrm{~cm}), 110$-day cycle and medium grain yield, its widely grown by farmers in the region.

\section{Experimental design}

The experiment was laid out in a randomized complete block design in a $2 \times 4$ factorial scheme with four replications. The first factor was the rice cultivars (Cambará and Comecru) and the second, the amounts of babassou straw on a wet basis $\left(0,15,20\right.$ and $\left.25 \mathrm{t} \mathrm{ha}^{-1}\right)$. The control corresponded to treatment $0 \mathrm{t} \mathrm{ha}^{-1}$ of straw, which is absence of straw and weed control. The plots consisted of five rows of $5.0 \mathrm{~m}$ in length spaced $0.5 \mathrm{~m}$ apart. The useful area was composed of the three central lines, excluding $0.5 \mathrm{~m}$ from the ends and totaling $6.0 \mathrm{~m}^{2}$.

At $10 \mathrm{DAE}$, green leaves (wet base) of babassou palm were collected from adult plants in the property, crushed in Trapp forage, model TRF 400, weighed according to the treatments and placed between the rows of the rice crop. Before placing the waste, weeding was carried out in all plots.

\section{Weed survey and identification}

Weed surveys were carried out in the rice harvest using the method described by Braun-Blanquet (1979), by means of an open rectangle measuring $0.50 \mathrm{~m} \times 0.30 \mathrm{~m}$ randomly thrown four times in each plot. Weeds were cut, identified by species (Lorenzi, 2008), and counted. Thereafter, they were placed in a greenhouse with forced air ventilation at $65^{\circ} \mathrm{C}$ until reaching a constant mass for weighing on a precision scale.

The results of density and dry mass of each species were used to compute the phytosociological parameters, including, relative density ( $R$ De), relative frequency ( $R \mathrm{Fr}$ ) and relative dominance ( $R$ Do), which were used to compute the importance value index (IVI), as proposed by MuellerDombois \& Ellemberg (1974).

\section{Assessment of rice cultivar variables}

During the flowering of rice cultivars, we measured the height of 20 rice plants in the useful area of the plots, taking the distance from the soil surface to the last basal node of the panicle. We harvested the crop manually when more than $95 \%$ of the panicles showed typical color of matured grains. To determine grain yield, moisture was corrected to $13 \%$ and converted into $\mathrm{kg} \mathrm{ha}^{-1}$.

\section{Statistical analyses}

The results of weed density, dry mass, rice plant height, weight of 100 grains (g), percentage of fertile panicles and the number of spikelets per panicle, and grain yield were 
submitted to analysis of variance, with application of the test Tukey, at $5 \%$ probability to compare the differences among the means of the tested factors. These analyzes were carried out with the Agroestat software (Barbosa and Maldonado Júnior, 2015).

\section{Conclusions}

Babassou straw mulching and rice cultivars influence the floristic composition and dynamics of the weed community. Babassou straw mulching suppresses weeds, reducing competition with both Comecru and Cambará rice cultivars and increases grain yield. Rice cultivars had higher plant heights in the presence of babassou straw mulching. Comecru Cv. showed significantly higher grain yield than Cambará cv. Babassou straw mulching, when applied between the rows of upland rice cultivars reduced weed density which demonstrates the potential of this residue as mulch to control weeds.

\section{Acknowledgements}

To the Fundação de Amparo à Pesquisa e ao Desenvolvimento Científico e Tecnológico do Maranhão FAPEMA for funding the research project, to the Coordenação de Aperfeiçoamento de Pessoal de Nível Superior - CAPES for the scholarship granted to the first author and to the Maranhão State University staff for technical support for conducting the experiment.

\section{References}

Ali HH, Tanveer A, Naeem M, Jamil $M$, lqbal M, Javaid MM, Kashif MS (2015) Efficacy of preemergence herbicides in controlling Rhynchosia capitata, an emerging summer weed in Pakistan. Philipp Agric Sci. 98(3):301-311.

Awan TH, Cruz PS, Chauhan BS (2015) Growth analysis and biomass partitioning of Cyperus iria in response to rice planting density and nitrogen rate. Crop Prot. 74:92-102.

Barbosa JC, Maldonado Júnior W (2015) AgroEstat: Sistema para Análises Estatísticas de Ensaios Agronômicos, Versão 1.0. FCAV/UNESP.

Braun-Blanquet J (1979) Fitossociologia: bases para el estúdio de las comunidades vegetales. 3rd edn. H. Blume, Madrid.

Chopra N, Tewari G, Tewari LM, Upreti B, Pandey N (2017) Allelopathic effect of Echinochloa colona L. and Cyperus iria L. weed extracts on the seed germination and seedling growth of rice and soyabean. In: Janda T (ed) J Adv Agric. Hindawi, Nainital, India,

Companhia Nacional de Abastecimento - CONAB Perspectivas para a agropecuária / Companhia Nacional de Abastecimento - v.1 - Brasília : Conab, 2019. https://www.conab.gov.br/info-agro/safras/graos.10 Abril, 2020.

Costa BP, Silva MRM, Rego CARM, Herrera JL, Cruz MSFV, Ristau ACP, Sampaio MC Alves TN, Oliveira SS, Braz H, Machado NAF (2018) Phytosociology and floristic composition of the infesting community in rice crop waterlogged. Am J Plant Sci. 9:353-367.
Dass A, Shekhawat K, Choudhary AK, Sepat S, Rathore SS, Mahajan G, Chauhan BS (2017) Weed management in rice using crop competition - a review. Crop Prot. 95:45-52.

Hussain S, Khaliq A, Matloob A, Fahad S, Tanveer A (2015) Interference and economic threshold level of little seed canary grass in wheat under different sowing times. Environ Sci Pollutt R. 22(1):441-449.

Jabran K, Ullah E, Hussain M, Farooq M, Zaman U, Yaseen $M$, Chauhan BS (2015) Mulching improves water productivity, yield and quality of fine rice under watersaving rice production systems. J Agron Crop Sci. 201(5):389-400.

Juang KW, Lin MC, Hou CJ (2021) Influences of water management combined with organic mulching on taro plant growth and corm nutrition. Plant Prod Sci. 24(2):152-169.

Khan MA, Marwat KB, Umm-E-Kulsoom Z, Hashim S, Rab A, Nawab K. (2013) Weed control effects on the wheat-pea intercropping. Pakistan J Bot. 45(5):1743-1748.

Lorenzi, H. (2008) Plantas daninhas do Brasil: terrestres, aquáticas, parasitas e tóxicas. 4a ed. Instituto Plantarum, Nova Odessa, SP.

Liu, D, Samtani JB, Johnson CS, Butler DM, Derr J (2020) Weed control assessment of various carbon sources for anaerobic soil disinfestation, Int J Fruit Sci. 20:1005-1018.

Mesquita MLR, Andrade LA, Pereira WE (2019) Ecological weed control in rice and maize using Orbygnia phalerata with focus on the weed seedbank in the soil. Aust J Crop Sci. 13(10):1683-1687.

Mueller-Dombois D, Ellemberg $\mathrm{H}$ (1974) Aims and methods of vegetation ecology. John Willey \& Sons, New York.

Nichols V, Verhulst N, Cox R, Govaerts B (2015) Weed dynamics and conservation agriculture principles: A review. Field Crop Res. 183:56-68.

Peerzada AM, Bajwa AA, Ali HH, Chauhan BS (2016) Biology, impact, and management of Echinochloa colona (L.) Link. Crop Prot. 83:56-66.

Prasad R (2011) Aerobic rice systems. Adv Agron.11:207-233. Ranaivoson L, Naudin K, Ripoche A, Rabeharisoa RL, Corbeels $M(2018)$ Is mulching an efficient way to control weeds? Effects of type and amount of crop residue in rainfed rice based cropping systems in Madagascar. Field Crop Res. 217:20-31.

Sana N, Bajwa R, Javaid A, Shoaib A (2017) Effect of biopower application on weed growth and yield of rice. Planta Daninha. 35:e017164872.

Sardana V, Mahajan G, Jabran K, Chauhan BS (2016) Role of competition in managing weeds: an introduction to the special issue. Crop Prot. 95:1-7.

Silva MRM, Cantanhede JD, Corrêa MJP, Mesquita MLR (2015) Phytosociology and interference of weeds in upland rice in Maranhão State, northeastern Brazil. Afr J Agric Res. 10(34):3412-3420.

Silva MRM, Costa EA, Corrêa MJP, Rodrigues AAC, Mesquita MLR (2017) Floristic and Phytosociology of Weeds in Upland Rice in the Humid Tropics. Planta Daninha. 35:1-11.

Wayayok A, Soom MAM, Abdan K, Mohammed U (2014) Impact of mulch on weed infestation in system of rice intensification (SRI) farming. Agric Agric Sci Procedia. 2:353 -360 . 